Hydrol. Earth Syst. Sci. Discuss., https://doi.org/10.5194/hess-2017-388

Manuscript under review for journal Hydrol. Earth Syst. Sci.

Discussion started: 17 July 2017

\title{
Spatio-temporal trends in observed and downscaled precipitation over Ganga Basin
}

\author{
Himanshu Arora ${ }^{1}$, Chandra Shekhar Prasad Ojha ${ }^{2}$, Wouter Buytaert ${ }^{3}$, Gujjanadu Suryaprakash \\ Kaushika $^{1}$ and Chetan Sharma ${ }^{1}$ \\ $5 \quad{ }^{1}$ Research Scholar, Department of Civil Engineering, Indian Institute of Technology Roorkee, Roorkee, 247667, India \\ ${ }^{2}$ Professor, Department of Civil Engineering, Indian Institute of Technology Roorkee, Roorkee, 247667, India \\ ${ }^{3}$ Senior Lecturer, Faculty of Engineering, Department of Civil and Environmental Engineering, Imperial College London, \\ U.K.
}

Correspondence to: Himanshu Arora (himanshuuaroraa@gmail.com)

10 Abstract. This paper focuses on the spatio-temporal trends of precipitation over the Ganga Basin in India for over 2 centuries. Trends in precipitation amounts are detected using observed data for historical period in 20th century and using downscaled precipitation data from 37 GCMs for 21st century. The ranking of 37 GCMs (from CMIP5 archive) is done employing a statistics based skill score. The best ranked GCM output is then bias corrected with observed precipitation prior to further analysis. The direction and magnitude of trend in annual and seasonal precipitation series is determined using

15 Mann Kendall's test statistic (ZMK) and Thiel Sen's Slope estimator ( $\beta$ ). The plots depicting the spatial variation of ZMK and $\beta$ are prepared which provides a comprehensive inter-scenario comparison of spatio-temporal trends in precipitation series. Highly non-uniform spatio-temporal trends are detected for observed precipitation series. It is observed that the precipitation for annual and southwest monsoon season is indicating a rising trend for all future emission scenarios in the region adjacent to Himalayas (northeast side of study area) but shows falling trends in the plains away from the Himalayas.

20 Insignificant trends are observed in pre-monsoon and winter season precipitation. An inter-emission-scenario comparison shows that for higher emission scenarios the annual and southwest monsoon precipitation is showing rising trends with increasing spatial dominance i.e. the area under rising trends increases as we observe it from low to high emission scenarios.

\section{Introduction}

The Ganga basin is of great social, economic and religious importance to India. The basin which is a part of northern plains of India is predominantly covered by fertile alluvial soils brought down by various tributaries of Ganga. Agriculture being the dominant economy sector in this basin is therefore dependent on rainfall. The monsoon season for the region is mainly in the months of June to September. Similar is the season for cultivation of Kharif season crops in India. Main Kharif crops are rice and millet, which are highly dependent on quantity and timing of availability of rain water. More than $85 \%$ of the total rainfall occurs in monsoon season in this region. Rabi crops are sown in winter and harvested in spring season. In India, the 
Hydrol. Earth Syst. Sci. Discuss., https://doi.org/10.5194/hess-2017-388

Hydrology and

Manuscript under review for journal Hydrol. Earth Syst. Sci.

Discussion started: 17 July 2017

Earth System

(c) Author(s) 2017. CC BY 4.0 License.

Sciences

Discussions

(c) (i)

main Rabi crop is wheat, for which the main source of water is groundwater and irrigation. Excess rainfall in this season may spoil the Rabi crops but on the contrary is beneficial to Kharif crops.

Interpreting the importance of rainfall in the region, this study is targeted for determining the possible future trends in precipitation for the area. Ganga basin is already of great interest to many researchers, hydrologists and water resource

5 planners. Few of them have already reported the trends in observed precipitation series in some regions which are subsets of Ganga basin (Kothyari et al. 1997; Duhan and Pandey 2013; Suryavanshi et al. 2013). They have utilized monthly time series of observed precipitation and aggregated them to annual and seasonal amount to capture the trends embedded in them. A number of studies related to trends analysis of rainfall/precipitation are reported in literature. Diversities are found in various studies from around the world which include not only temporal trends but also spatial trends in precipitation patterns,

10 out of which some of them are enlisted in Table 1. The studies are based on rainfall/precipitation on various time scales such: annual extreme of 5-30 min and 1-12 h rainfall (Adamowski et al. 2003), annual total rainfall, seasonal total rainfall (as per most of the authors enlisted in Table 1); whereas as in few studies, researchers have focused on rainfall amounts of a particular season only such as monsoon season rainfall (Bashistha et al. 2009). Some authors have also utilized certain indices for trend detection such as frequency indices in daily rainfall for total, light, moderate, intense and very intense

15 rainfall (Gallego et al. 2011), seasonality index (Celleri et al. 2007). Most of the researchers have used rain-gauge station data, whereas few of them have considered data for meteorological subdivisions of a region for trend analysis (Guhathakurta and Rajeevan, 2008).

Popular methods used by researchers for trend analysis of rainfall/precipitation time series are parametric linear regression analysis (Guhathakurta and Rajeevan 2008; Caloiero et al. 2011; Kumar et al. 2013), robust locally weighted regression

20 (Kothyari et al. 1997), non-parametric Mann-Kendall's test (used by most of the authors enlisted in Table 1), modified Mann-Kendall’s Test (Bashistha et al. 2009), Sen’s slope estimator (Gallego et al. 2011; Barua et al. 2013; Duhan et al. 2013; Suryavanshi et al. 2013). Jain and Kumar (2012) have shown insignificant Sen’s slope estimates for annual as well as seasonal observed rainfall series in Ganga Basin as a whole. Duhan and Pandey (2013) have also observed a dominating negative trend at most of the rain gauge stations except for a few in the study area which lies in western part of Ganga Basin.

25 Arora et al. (2016) have provided a scenario-wise comparison of downscaled rainfall over a upper Yamuna sub-basin.

A number of agencies have developed their own GCMs following the norms provided by Intergovernmental Panel on Climate Change, yet every GCM cannot be stated as ideal for a particular location. Ranking for best fitting GCMs is done on the basis of skill scores which are subsequently based on certain statistical parameters in order to determine the GCMs with best precipitation capturing capability (Perkins et al., 2007; Ojha et al., 2013)

30 In this study, along with the spatial and temporal trends in annual and seasonal precipitation, future-emission-scenario-wise trends are also presented. For this, the observed and downscaled precipitation data is used which is made available by various sources in gridded form. Ranking is done on the basis of skill score which is further based on various statistical parameters and other statistics. Bias correction is performed on downscaled precipitation to reduce the systematic biases present in them. After that the trend analysis is performed on observed and bias-corrected downscaled precipitation series 
Hydrol. Earth Syst. Sci. Discuss., https://doi.org/10.5194/hess-2017-388

Manuscript under review for journal Hydrol. Earth Syst. Sci.

Discussion started: 17 July 2017

(c) Author(s) 2017. CC BY 4.0 License.

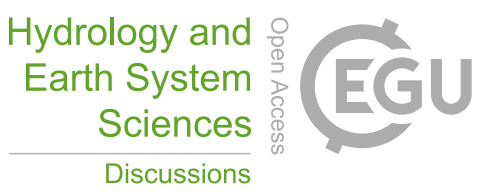

(c) (i)

over the entire study area. The methods used for this purpose are Mann-Kendall's test and Thiel-Sen's slope estimator. The details of study area and methodology followed are discussed in subsequent sections. 
Hydrol. Earth Syst. Sci. Discuss., https://doi.org/10.5194/hess-2017-388

Manuscript under review for journal Hydrol. Earth Syst. Sci.

Discussion started: 17 July 2017

(c) Author(s) 2017. CC BY 4.0 License.

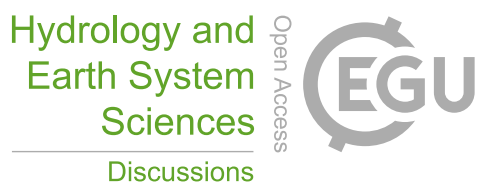

(c) $\underset{\mathrm{BY}}{(i)}$

Table 1: Summary of studies related to trend analysis of rainfall/precipitation

\begin{tabular}{|c|c|c|c|}
\hline No. & References and study area & Duration and data length & Methods employed \\
\hline \multicolumn{4}{|c|}{ Studies around the World } \\
\hline 1 & $\begin{array}{l}\text { Lettermaier et al. (1994) } \\
1036 \text { stations in continental United } \\
\text { States }\end{array}$ & $\begin{array}{l}\text { monthly precipitation for data between 1948- } \\
1988\end{array}$ & $\begin{array}{l}\text { Nonparametric seasonal Kendall's test, } \\
\text { Thiel-Sen's slope }\end{array}$ \\
\hline 2 & $\begin{array}{l}\text { Adamowski et al. (2003) } \\
44 \text { rainfall stations in Ontario, } \\
\text { Canada }\end{array}$ & $\begin{array}{l}\text { annual extreme of 5,10,15, } 30 \text { min and 1, 2, } 6 \\
\text { and } 12 \text { h rainfall with } 20 \text { years data }\end{array}$ & $\begin{array}{l}\text { Regional average Mann-Kendall S trend } \\
\text { test, L moments method, A bootstrap } \\
\text { methodology }\end{array}$ \\
\hline 3 & $\begin{array}{l}\text { Celleri et al. (2007) } \\
23 \text { rainfall stations, Paute Basin, } \\
\text { Ecuadorian Andes }\end{array}$ & $\begin{array}{l}\text { seasonality index and; } \\
\text { annual, seasonal and monthly rainfall for data } \\
\text { between 1964-1998 }\end{array}$ & Two sided Mann-Kendall’s test \\
\hline 4 & $\begin{array}{l}\text { Aldrian et al. (2008) } \\
40 \quad \text { rainfall stations, Brantas } \\
\text { Catchment Area (DAS Brantas), East } \\
\text { Java }\end{array}$ & $\begin{array}{l}\text { annual changes in monthly and seasonal } \\
\text { rainfall with } 50 \text { years data (1955-2005) }\end{array}$ & $\begin{array}{l}\text { Empirical Orthogonal Function (based on } \\
\text { multivariate statistics), non-parametric } \\
\text { Mann-Kendall Test, Wavelet Transform } \\
\text { Method }\end{array}$ \\
\hline 5 & $\begin{array}{l}\text { Beecham and Chowdhary (2010) } \\
\text { Melbourne, Australia }\end{array}$ & $\begin{array}{l}\text { point rainfall (rainfall intensities at } 0.1,0.5,1 \text {, } \\
3,6,12 \mathrm{~h} \text { and monthly) for data between } \\
1925-2002\end{array}$ & $\begin{array}{l}\text { Statistical moments, lag1 autocorrelation, } \\
\text { the Buishand's Q test, Mann-Kendall test } \\
\text { and wavelet analysis }\end{array}$ \\
\hline 6 & $\begin{array}{l}\text { Gallego et al. (2011) } \\
27 \text { stations in Portugal and Spain, } \\
\text { Iberian Peninsula }\end{array}$ & $\begin{array}{l}\text { frequency indices in daily rainfall (total, light, } \\
\text { moderate, intense and very intense rainfall) } \\
\text { for data between1903-2003 }\end{array}$ & Mann-Kendall test, Sen’s slope estimator \\
\hline 7 & $\begin{array}{l}\text { Caloiero et al. (2011) } \\
109 \text { rain gauge stations, Calabria } \\
\text { (Southern Italy) }\end{array}$ & $\begin{array}{l}\text { annual and seasonal rainfall with } 50 \text { years } \\
\text { data }\end{array}$ & $\begin{array}{l}\text { Mann-Kendall test, parametric linear } \\
\text { regression analysis }\end{array}$ \\
\hline 8 & $\begin{array}{l}\text { Iwasaki (2012) } \\
758 \text { stations in Eastern Japan }\end{array}$ & $\begin{array}{l}\text { hourly rainfall amounts for June and } \\
\text { September with } 31 \text { years data }(1976-2006)\end{array}$ & Non-parametric Wilcoxon rank-sum test \\
\hline 9 & $\begin{array}{l}\text { Casimiro et al. (2013) } \\
58 \text { stations in Peruvian Amazon- } \\
\text { Andes basin }\end{array}$ & $\begin{array}{l}\text { annual and seasonal rainfall with } 40 \text { years } \\
\text { data }\end{array}$ & $\begin{array}{l}\text { Mann-Kendall non- parametric test, } \\
\text { Pettitt non-parametric test }\end{array}$ \\
\hline 10 & $\begin{array}{l}\text { Barua et al. (2013) } \\
15 \text { rainfall stations, Yarra River } \\
\text { catchment, Victoria, Australia }\end{array}$ & $\begin{array}{l}\text { monthly and annual rainfall with } 54 \text { years } \\
\text { data (1953-2006) }\end{array}$ & $\begin{array}{l}\text { Mann-Kendall test, Sen’s slope estimator, } \\
\text { CUSUM test, pre-whitening criteria test }\end{array}$ \\
\hline 11 & $\begin{array}{l}\text { Kumar et al. (2013) } \\
14 \text { stations in Fiji }\end{array}$ & $\begin{array}{l}\text { annual, wet and dry seasonal rainfall with } 100 \\
\text { years data }\end{array}$ & Linear Regression \\
\hline \multicolumn{4}{|c|}{ Studies in India } \\
\hline 1 & $\begin{array}{l}\text { Guhathakurta and Rajeevan (2008) } \\
36 \text { meteorological subdivisions of } \\
\text { India }\end{array}$ & $\begin{array}{l}\text { monthly, seasonal and annual rainfall for data } \\
\text { between 1901-2003 }\end{array}$ & Linear regression \\
\hline 2 & $\begin{array}{l}\text { Guhathakurta et al. (2011) } \\
2599 \text { raingauge stations all over India }\end{array}$ & $\begin{array}{l}\text { annual one-day extreme rainfall with } 30 \text { years } \\
\text { (and more) data }\end{array}$ & $\begin{array}{l}\text { Mann-Kendall's test, least square linear } \\
\text { fit }\end{array}$ \\
\hline \multicolumn{4}{|c|}{ Studies in Ganga Basin } \\
\hline 1 & $\begin{array}{l}\text { Kothyari et al. (1997) } \\
3 \text { stations Agra, Dehradun and Delhi } \\
\text { in Ganga Basin, India }\end{array}$ & $\begin{array}{l}\text { total monsoon rainfall with } 89 \text { years data } \\
\text { (1901-1989) }\end{array}$ & $\begin{array}{l}\text { robust locally weighted regression, Mann- } \\
\text { Kendall test }\end{array}$ \\
\hline 2 & $\begin{array}{l}\text { Bashistha et al. (2009) } \\
30 \text { rain gauge stations in Indian } \\
\text { Himalayas }\end{array}$ & $\begin{array}{l}\text { annual and monsoon rainfall with } 80 \text { years } \\
\text { data (1901-1980) }\end{array}$ & $\begin{array}{l}\text { Modified Mann-Kendall Test, Pettitt- } \\
\text { Mann-Whitney test }\end{array}$ \\
\hline 3 & $\begin{array}{l}\text { Duhan et al. (2013) } \\
45 \text { stations, Madhya Pradesh, India }\end{array}$ & $\begin{array}{l}\text { annual and seasonal precipitation with } 102 \\
\text { years data (1901-2002) }\end{array}$ & $\begin{array}{l}\text { Mann-Kendall Test, Thiel-Sen's slope } \\
\text { estimator, Cumulative deviations test and } \\
\text { Mann-Whitney-Pettitt method }\end{array}$ \\
\hline 4 & $\begin{array}{l}\text { Suryavanshi et al. (2013) } \\
\text { Betwa Basin, India }\end{array}$ & $\begin{array}{l}\text { annual and seasonal precipitation (monsoon, } \\
\text { winter and summer) }\end{array}$ & $\begin{array}{l}\text { Mann-Kendall Test, Thiel-Sen's slope } \\
\text { estimator }\end{array}$ \\
\hline 5 & $\begin{array}{l}\text { Arora et al. (2016) } \\
\text { Yamuna-Hindon Interbasin, India }\end{array}$ & monthly precipitation series & scenario-wise comparison \\
\hline
\end{tabular}


Hydrol. Earth Syst. Sci. Discuss., https://doi.org/10.5194/hess-2017-388

Manuscript under review for journal Hydrol. Earth Syst. Sci.

Discussion started: 17 July 2017

(c) Author(s) 2017. CC BY 4.0 License.
Hydrology and

Earth System

Sciences

Discussions

\section{Study Area and Data Used}

\subsection{Ganga Basin}

India lies in a tropical monsoon climate zone with spatially diversified rainfall pattern (Guhathakurta et al. 2011). The study area considered is the portion of Ganga basin which lies in India only. It lies between latitudes from $21.25^{\circ} \mathrm{N}$ to $31.5^{\circ} \mathrm{N}$ and longitudes from $73.25^{\circ} \mathrm{E}$ to $89.25^{\circ} \mathrm{E}$. As per the Köppen-Geiger climate type map of Asia (Peel et al. 2007), the study area predominantly lies in humid-subtropical climatic zone of India. A smaller region of it in the western most part lies in semiarid zone, whereas the downstream-most part of it lies in tropical wet and dry zone of India. The length of main stream of Ganga is more than $2500 \mathrm{kms}$ and the catchment area is about $20 \%$ of the total geographical area of India. The River Ganga originates in the laps of Himalayas (at Gaumukh), flows eastwards through the northern plains of India and finally drains into the Bay of Bengal, forming the biggest delta in the world along with the River Brahmaputra. Along its complete stretch, many tributaries unite themselves with the Ganga at various locations. Tributaries like Gomati, Ghaghra and Gandak conjoins with main stream of Ganga from the northern side. These tributaries are glacier fed and are perennial. Whereas tributaries like Chambal, Sind, Betwa, Ken and Son conjoins it from the southern side.
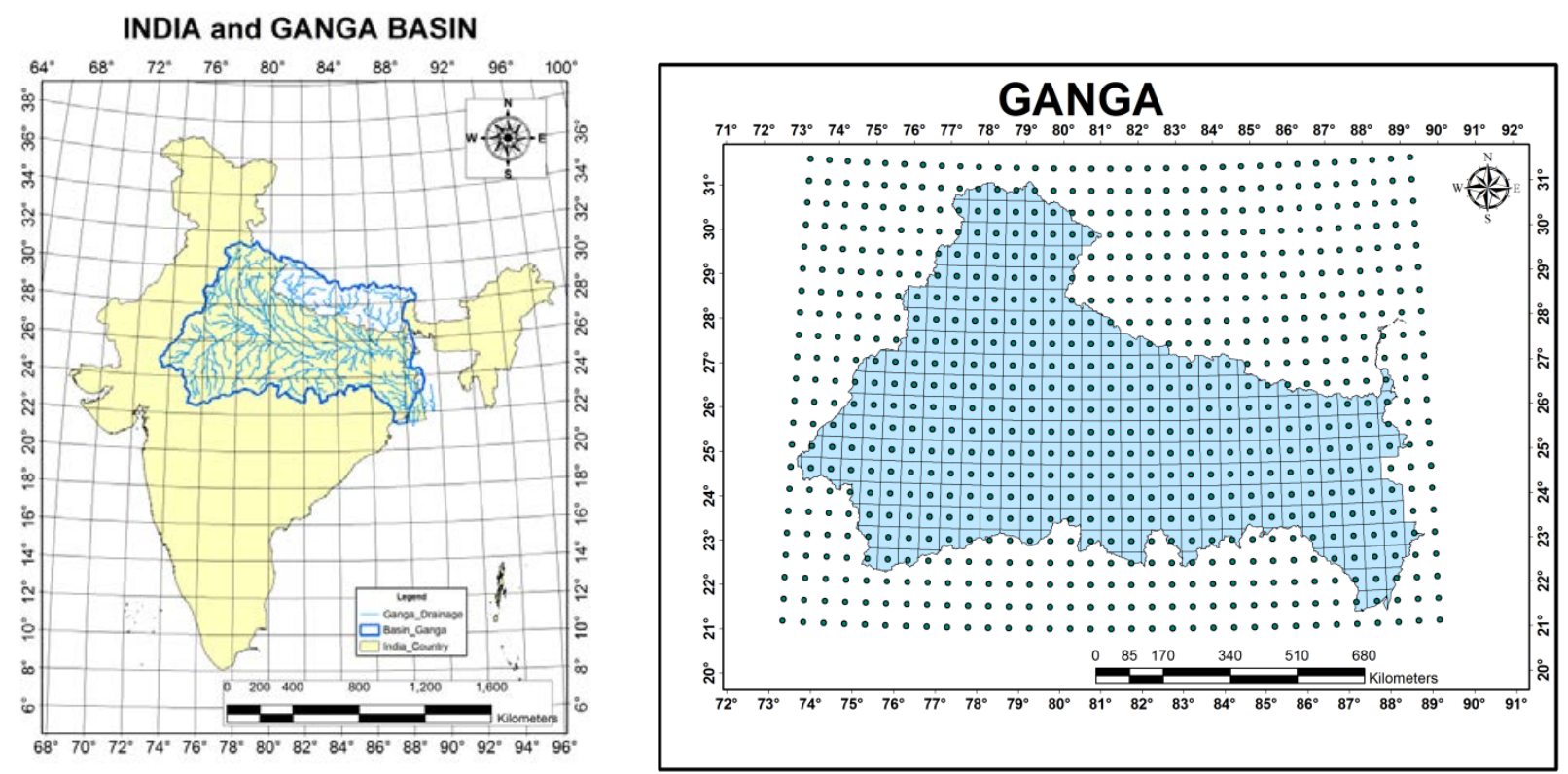

15 Figure 1: Study Area - Ganga Basin

\subsection{Precipitation Data Used}

The precipitation dataset used for the study in this paper consists of gridded observed and downscaled precipitation.

Observed Precipitation data (Pobs): The observed daily precipitation is made available by the Indian Meteorological Department (IMD) in gridded form for the time period ranging between January 1901 and December 2015. The horizontal 
Hydrol. Earth Syst. Sci. Discuss., https://doi.org/10.5194/hess-2017-388

Manuscript under review for journal Hydrol. Earth Syst. Sci.

Discussion started: 17 July 2017

(c) Author(s) 2017. CC BY 4.0 License.

resolution of this data in geographical coordinates is $0.25^{\circ} \mathrm{x} 0.25^{\circ}$ (latitudes $\mathrm{x}$ longitudes). For this study, seasonal and annual aggregate amount of precipitation is computed and used for analysis. The meteorological seasons considered in the study area (as per IMD definition) are: southwest monsoon season (Jun-Sep), northeast monsoon season (Oct-Dec, also termed as post-monsoon), winter season (Jan-Feb), and pre-monsoon season (Mar-May). From now onwards in this paper, these seasons are denoted by SWM, NEM, WS and PM respectively.

Downscaled Precipitation data: Downscaled CMIP5 climate and hydrology projections are obtained from archive at http://gdo-dcp.ucllnl.org/downscaled_cmip_projections/ (Maurer et al. 2007). The precipitation was downscaled using the bias-correction and spatial disaggregation (BCSD) method. Downscaled precipitations for 37 GCMs from CMIP5 archive (ensemble r1i1p1) are used in this study. The GCMs are enlisted in Table 2. The horizontal resolution of this data in 10 geographical coordinates is $0.5^{\circ} \times 0.5^{\circ}$ (latitudes $\mathrm{x}$ longitudes). This data is available for various emission scenarios such as: RCP2.6, RCP4.5, RCP6.0 and RCP8.5 (for CMIP5). As per the 5th assessment report (AR5) of IPCC (2013), the newer families of emission scenarios are introduced which are termed as Representative Concentration Pathways (RCPs) (Vuuren et al. 2011). RCPs are referred according to radiative forcing target level of greenhouse gases and other forcing agents for year 2100. RCP2.6 is termed as a mitigation scenario leading to a very low forcing level with peak in radiative forcing at $\sim 3$

$15 \mathrm{~W} / \mathrm{m} 2$ ( $\sim 90$ ppm CO2 equivalent) before 2100 and then decline. RCP4.5 and RCP6.0 are two medium stabilization scenarios, which corresponds to stabilization without overshoot pathway to $4.5 \mathrm{~W} / \mathrm{m} 2$ ( $650 \mathrm{ppm}$ CO2 equivalent) and 6 $\mathrm{W} / \mathrm{m} 2$ ( $\sim 50$ ppm CO2 equivalent) respectively, at stabilization after year 2100. RCP8.5 is termed as a very high baseline emission scenario with rising radiative forcing pathway leading to $8.5 \mathrm{~W} / \mathrm{m} 2$ ( $1370 \mathrm{ppm}$ CO2 equivalent) by year 2100.

Length of the data considered for the fulfilment of objective of this paper is 56 years for observed data (1950 to 2005) and 95

20 years for CMIP5 data (2006-2100) for all future emission scenarios (RCP2.6, RCP4.5, RCP6.0 and RCP8.5). The spatial resolution of data considered for further analysis is $0.5^{\circ} \mathrm{x} 0.5^{\circ}$ (latitudes $\mathrm{x}$ longitudes). A total of 358 grid point covers the study area as shown in Fig.1. As the data is available for multiple GCMs (37 CMIP5), ranking of GCMs for downscaled monthly precipitation is done on the basis of a skill score, which is discussed later. The monthly precipitation series is then aggregated annually and seasonally (SWM, NEM, WS and PM). For comparison of downscaled precipitation dataset from different CMIP archives over Ganga basin, the spatial variation of seasonal and annual means of precipitation time series over Ganga basin are plotted as shown in Fig. 2. It can be inferred from this figure that in Ganga Basin, major percentage of observed annual precipitation occurs in southwest monsoon season (about $85 \%$ ), where as a smaller percentage of it occurs in post monsoon (about 6\%) and pre-monsoon season (about 6\%). 
Hydrol. Earth Syst. Sci. Discuss., https://doi.org/10.5194/hess-2017-388

Table 2 List CMIP5 GCMs and developer agencies

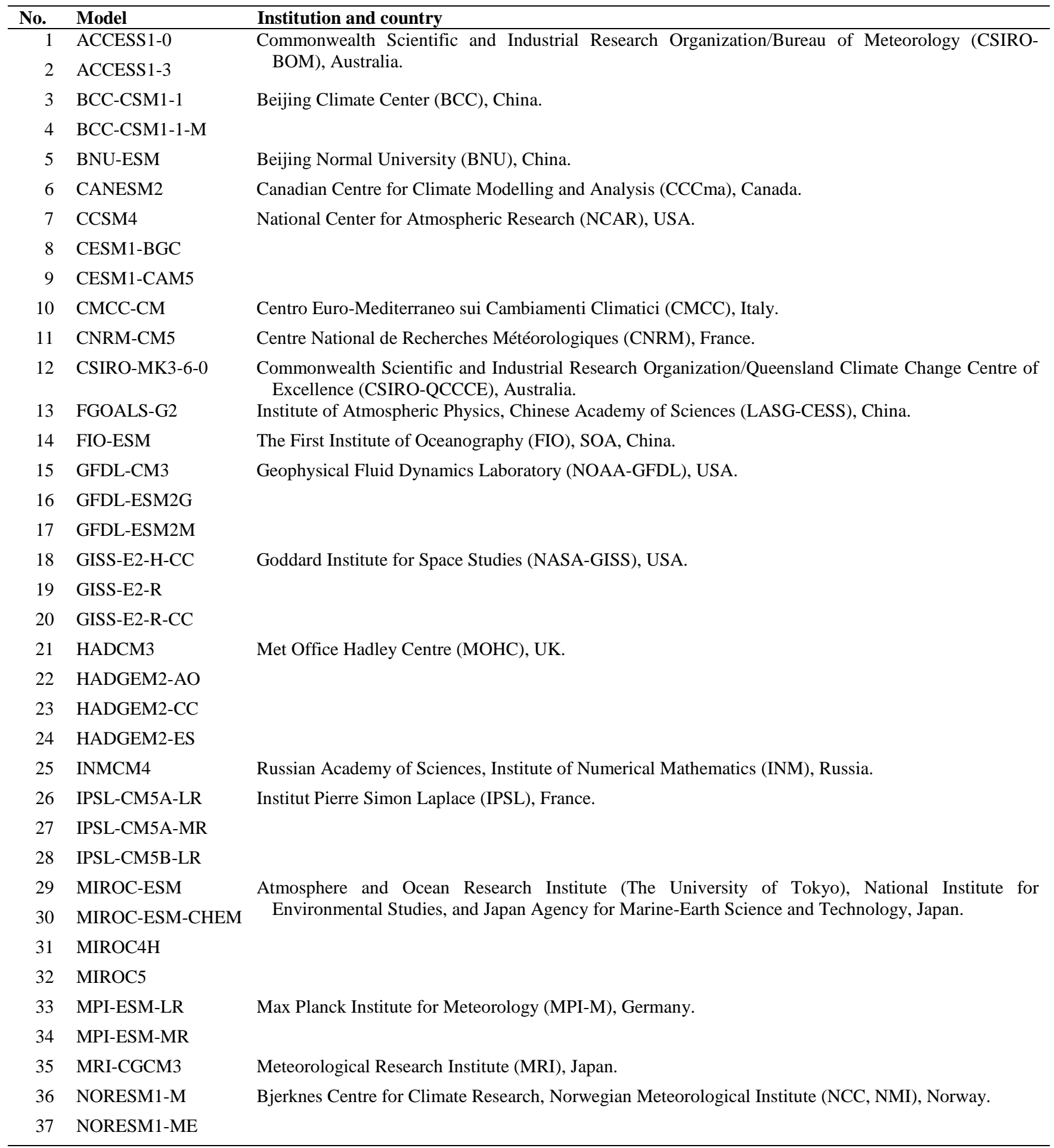


Hydrol. Earth Syst. Sci. Discuss., https://doi.org/10.5194/hess-2017-388

Manuscript under review for journal Hydrol. Earth Syst. Sci.

Discussion started: 17 July 2017

(c) Author(s) 2017. CC BY 4.0 License.
Hydrology and

Earth System

Sciences

Discussions
MEANS

Obs.

Annual

RCP2.6
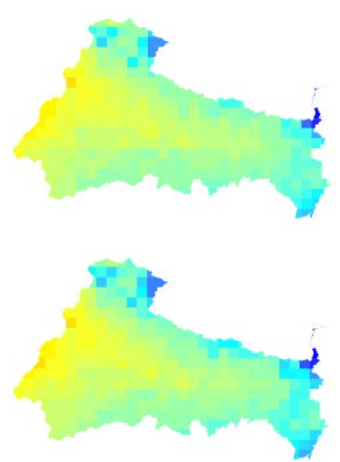

RCP4.5

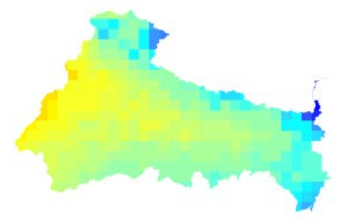

RCP6.0
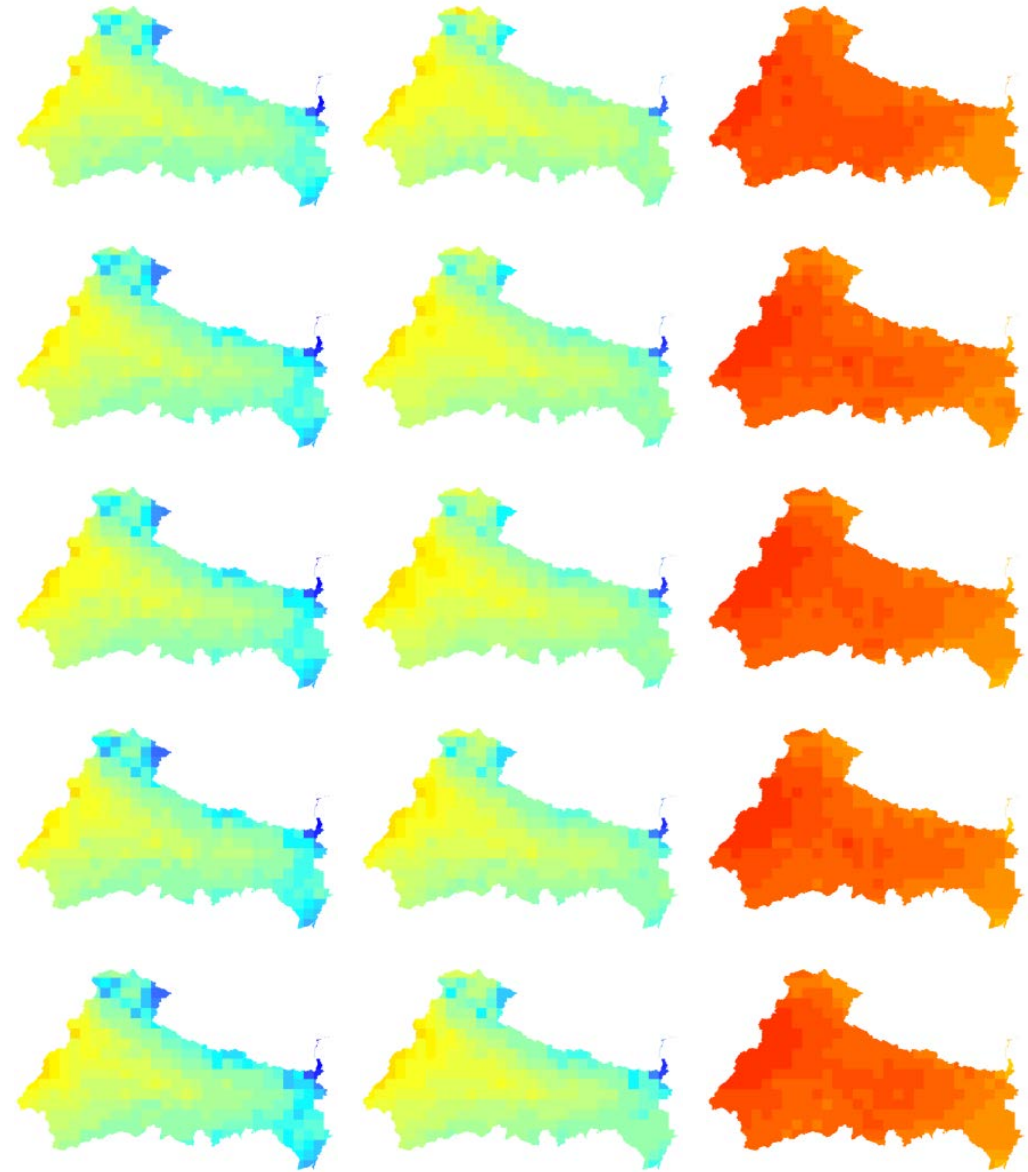

RCP8.5
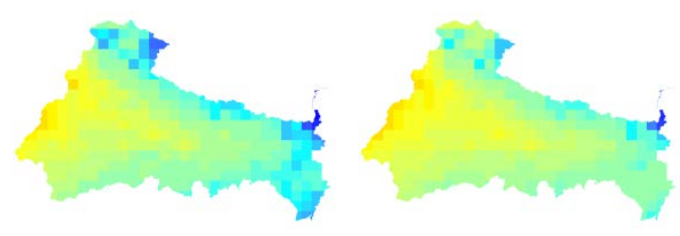
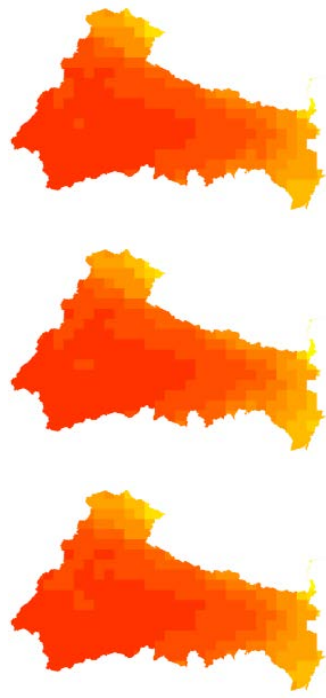

PM
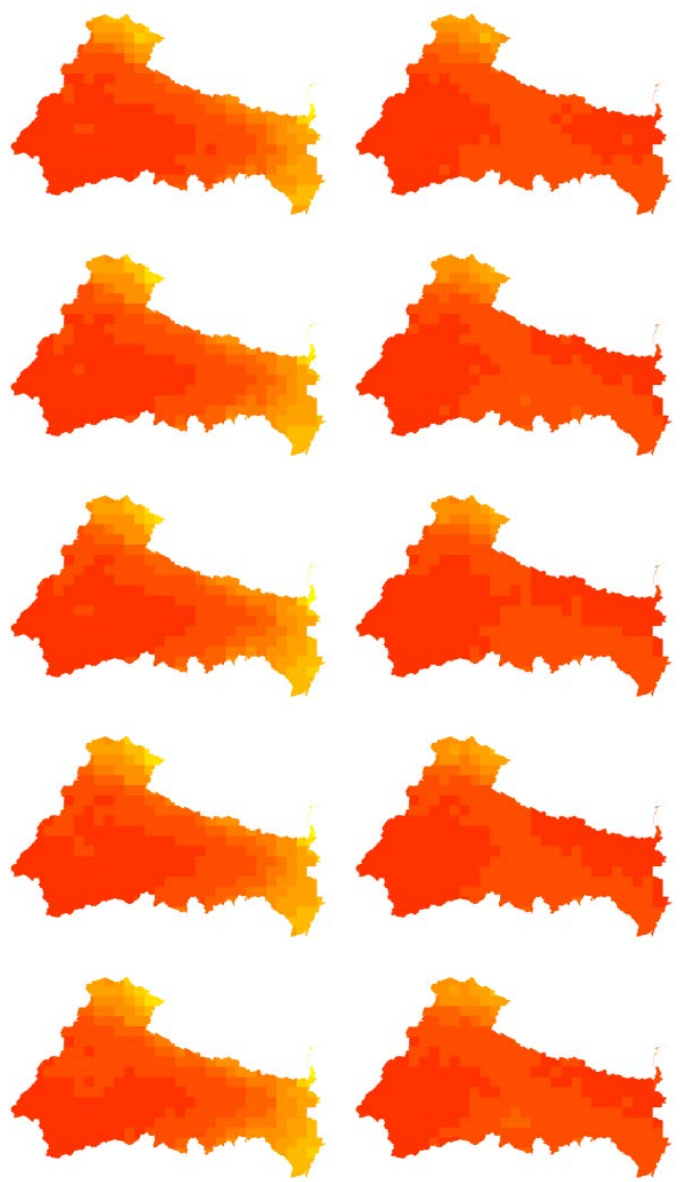
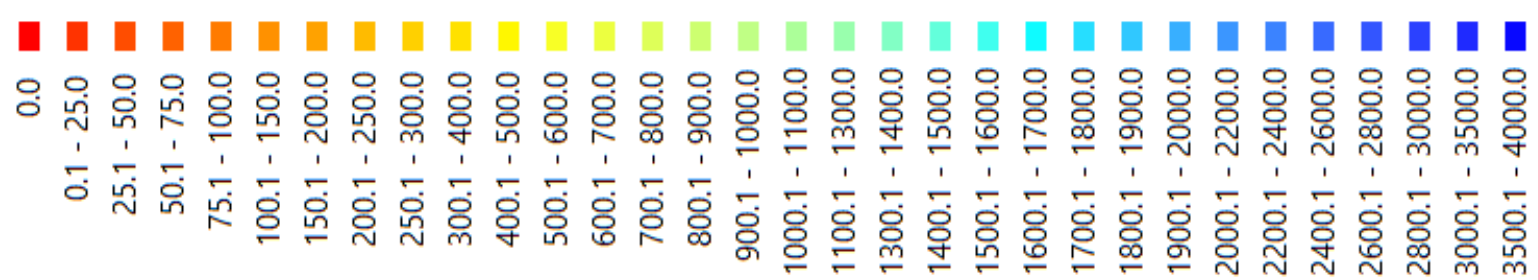

Figure 2: Long term means of annual and seasonal (SWM, NEM, PM and WS) aggregates of precipitation amount.

\section{Methodology}

The methodology followed in this paper includes: skill score based ranking of GCMs; bias correction of best performing GCM output w.r.t. observed precipitation; trend analysis on the basis of non-parametric Mann-Kendall test statistic and Thiel 5 Sen's slope estimator. 
Hydrol. Earth Syst. Sci. Discuss., https://doi.org/10.5194/hess-2017-388

Manuscript under review for journal Hydrol. Earth Syst. Sci.

Discussion started: 17 July 2017

(c) Author(s) 2017. CC BY 4.0 License.
Hydrology and

Earth System

Sciences

Discussions

(c) $\underset{\mathrm{BY}}{\mathrm{BY}}$

\subsection{Ranking of GCMs}

Various researchers have practiced the ranking of GCMs for the purpose of getting better estimates of downscaled precipitation. In Fig. 3, just by visual inspection, it can be inferred that there is a large variability in predicted values of target variable, when an ensemble of GCMs is considered. Therefore ranking of GCMs is necessary to determine the GCMs in best agreement with observed data. Raju et al. (2016) have practiced a compromise programming based methodology for ranking of CMIP5 based GCMs for evaluating the performance of maximum and minimum temperature (Tmax and Tmin) simulations over India. For determining the performance of GCM for prediction of different hydro-meteorological variables, skill scores based ranking methods are also exercised by respective authors. (Anandhi and Nanjundiah, 2015; Fu et al., 2013).

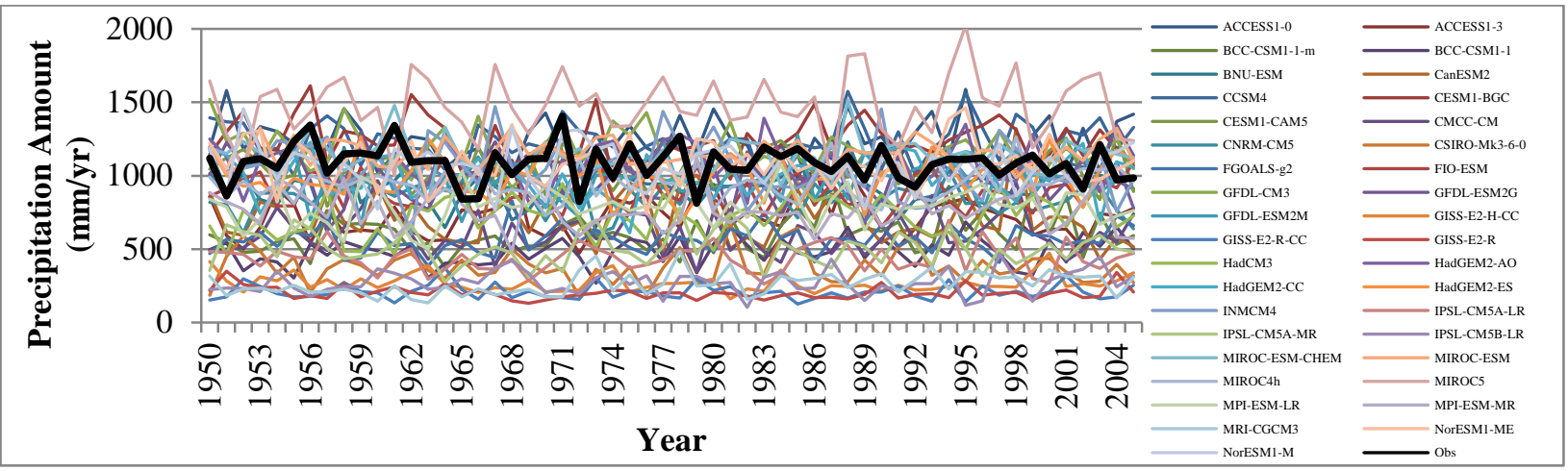

Figure 3: Annual precipitation time series plots for observed and CMIP5 data for historical period (1950-2005)

In this study, for evaluating the performance of GCM in simulating the precipitation series, ranking of GCMs is done based on an skill score (SS). This skill score is developed based on combined magnitude of several statistical measures. These are: coefficient of correlation (CC), absolute relative error in: means (REMN), standard deviation (RESD), coefficient of

15 skewness (RECS), coefficient of kurtosis (RECK), Mann-Kendall statistic (REMK) (Kendall 1975), Thiel-Sen's slope (RETS) (Thiel 1950; Sen 1968), shape and scale parameters of gamma distribution (REG1 and REG2). The lower the value of SS the better will be the performance of GCM in predicting the precipitation for an area.

$$
S S=(1-C C)+|R E M N|+|R E S D|+|R E C S|+|R E C K|+|R E M K|+|R E T S|+|R E G 1|+|R E G 2|
$$

Spatially averaged skill score (SASS) is obtained by averaging the SS values over study area. The formula is as shown below.

$$
S A S S=\frac{\sum_{n=1}^{P} S S_{P}}{P}
$$

Where, SSp = skill score at a particular grid point, $\mathrm{P}=$ number of grid points covering the study area. 
Hydrol. Earth Syst. Sci. Discuss., https://doi.org/10.5194/hess-2017-388

\subsection{Bias Correction}

Even after determining the best performing GCM in predicting precipitation, there are still some biases present in the downscaled precipitation series. To remove those biases, an equi-probability transformation based bias-correction technique is applied to downscaled precipitation series. Here the cumulative distribution functions are obtained for observed

5 precipitation and downscaled precipitation for baseline period (historical scenario). Using these two CDF, the projected precipitation series is bias-corrected for historical as well as future emission scenarios (RCP 2.6, RCP 4.5, RCP 6.0 and RCP 8.5). The detailed procedure is being illustrated by Ghosh and Mujumdar (2008) and Arora et al. (2016).

\subsection{Trend Analysis}

For comparison purpose, the long-term means of precipitation time series for observed and downscaled values are computed

10 which are shown in Fig. 2. In this paper, the methods used for trend detection are: Mann-Kendall's test and Thiel-Sen’s slope estimator.

Few researchers have emphasized on pre-whitening of precipitation time series prior to trend analysis due to the presence of serial correlation effect in a series. According to Partal and Kahya (2006), this effect may cause inaccuracy and misinterpretation in trend detection of a hydrologic time series. But in case the sample size is large enough ( $\mathrm{n}>70)$, few

15 researchers (Yue and Wang 2002; Bayazit and Onoz 2007) have recommended not to perform pre-whitening of dataset as the serial correlation does not have a major effect on MK test as well as it may cause reduction of power in it.

\subsubsection{Mann-Kendall's test for trend detection}

The rank-based non-parametric Mann-Kendall’s test (Mann 1945; Kendall 1975) is applied to seasonal and annual total precipitation time series for observed and downscaled dataset. Being non-parametric in nature, this test have several

20 advantages over parametric test for trend detection in hydrologic series, such as: (1) normality in data and homogeneity in its variance need not be assumed, (2) no effect of outliers on its performance since it compare central values such as medians rather than means, (3) transformation of data is also not required due to its non-parametric nature, (4) performs effectively for the dataset even if it's distribution is skewed in nature (5) can be employed to the dataset below detection limit as it uses the relative position of data points with each other. (Helsel 1987)

25 The null hypothesis $\left(\mathrm{H}_{0}\right)$ for this test which is applied on annual as well as seasonal precipitation is: the time series data has no trend and the data is a series of identical and independently distributed random variables (Gallego et al. 2011). Whereas the alternate hypothesis $\left(\mathrm{H}_{1}\right)$ for the same is: the time series data has a significant rising or falling trend. For this, ' $\mathrm{s}$ ' statistic is calculated as shown in Eq. (3) and (4). The mean and variance of 's' under null hypothesis, can be calculated as shown in Eq. (5). Thereafter, Mann Kendall statistic $\left(\mathrm{Z}_{\mathrm{MK}}\right)$ is calculated which is normally distributed with zero mean and unit 30 standard deviation. The positive value of $\mathrm{Z}_{\mathrm{MK}}$ shows a rising trend and a negative value of it indicates a falling trend in the series. In this study, the significance of $\mathrm{Z}_{\mathrm{MK}}$ is observed on confidence level $90 \%, 95 \%$ and $99 \%$. 
Hydrol. Earth Syst. Sci. Discuss., https://doi.org/10.5194/hess-2017-388

Manuscript under review for journal Hydrol. Earth Syst. Sci.

Discussion started: 17 July 2017

(c) Author(s) 2017. CC BY 4.0 License.

(c) (i)

$$
\begin{aligned}
& s=\sum_{i=1}^{n-1} \sum_{j=i+1}^{n} \operatorname{signum}\left(p_{j}-p_{i}\right) \\
& \operatorname{signum}\left(p_{j}-p_{i}\right)=\left\{\begin{array}{c}
1 \ldots \ldots \ldots \text { if }\left(p_{j}-p_{i}\right)>0 \\
0 \ldots \ldots . . \text { if }\left(p_{j}-p_{i}\right)=0 \\
-1 \ldots \ldots \ldots \text { if }\left(p_{j}-p_{i}\right)<0
\end{array}\right. \\
& E(s)=0 ; \operatorname{Var}(s)=\frac{n(n-1)(2 n+5)-\sum_{i=1}^{T} t_{i}\left(t_{i}-1\right)\left(2 t_{i}+5\right)}{18} \\
& Z_{M K}(s)=\left\{\begin{array}{c}
\frac{s-1}{\sqrt{\operatorname{Var}(s)}} \ldots \ldots \ldots . \text { if } s>0 \\
0 \\
\frac{s+1}{\sqrt{\operatorname{Var}(s)}} \ldots \ldots \ldots . . . . . . \text { if } s<0
\end{array}\right.
\end{aligned}
$$

5 Where, $p_{j}$ and $p_{i}=$ data points of precipitation time series, $Z_{M K}=$ test statistic for Mann Kendall test, $\mathrm{E}(*)=$ Expected value, $\operatorname{Var}\left({ }^{*}\right)=$ variance, $\mathrm{n}=$ length of precipitation time series (in years), $\mathrm{T}=$ number of ties in precipitation time series, $\mathrm{t}_{\mathrm{i}}=$ number of data point for $\mathrm{i}^{\text {th }}$ tie.

\subsubsection{Thiel Sen's slope estimator}

Although the Mann Kendall test shows its proficiency in detecting trends in a time series but does not provide slope estimates. Therefore Hirsch (1982) proposed a method for this using Thiel-Sen’s slope estimator. The Thiel-Sen's slope ( $\beta$ ) is used to determine the magnitude of trend in terms of its slope (Thiel 1950a, 1950b, 1950c; Sen 1968). Assumption of linear slope is applied to this method. Unlikely linear regression method, the Thiel-Sen's slope is insensitive to the presence of extreme values in the data series (Lettermaier et al. 1994), as it requires calculation of median. In this study, it is employed on seasonal and annual total precipitation time series. The slopes are determined between all data points of

15 precipitation time series and the median of all slopes results in $\beta$. For a data series of size $\mathrm{n}$, the total number of slopes will be ${ }^{\mathrm{n}} \mathrm{C}_{2}$ (i.e., $\left.\mathrm{n}(\mathrm{n}-1) / 2\right)$. The $\beta$ is formulated as shown in Eq. 7.

$$
\beta=\operatorname{Median}\left(\frac{p_{j}-p_{i}}{j-i}\right) \quad \text { for all } i<j
$$

Where, $p_{j}$ and $p_{i}=$ data points of precipitation time series, $\mathrm{i}$ and $\mathrm{j}=$ indices of data points. 
Hydrol. Earth Syst. Sci. Discuss., https://doi.org/10.5194/hess-2017-388

Manuscript under review for journal Hydrol. Earth Syst. Sci.

Discussion started: 17 July 2017

(c) Author(s) 2017. CC BY 4.0 License.
Hydrology and

Earth System

Sciences

Discussions

(c) (1)

\section{Results and Discussion}

\subsection{Ranking of GCMs}

The SASS is calculated and ranking is done on its basis. The minimum score is obtained for the GCM named CESM1CAM5 (GCM no. 9 in Table 2) developed by National Center for Atmospheric Research, USA. HadCM3 (Met Office

5 Hadley Centre, UK) and IPSL-CM5A-MR (Institut Pierre Simon Laplace, France) holds second and third rank in skill for prediction of precipitation over Ganga basin. Fig 4 shows the SASS of all the 37 GCM in order of their ability to predict the precipitation in the study area.

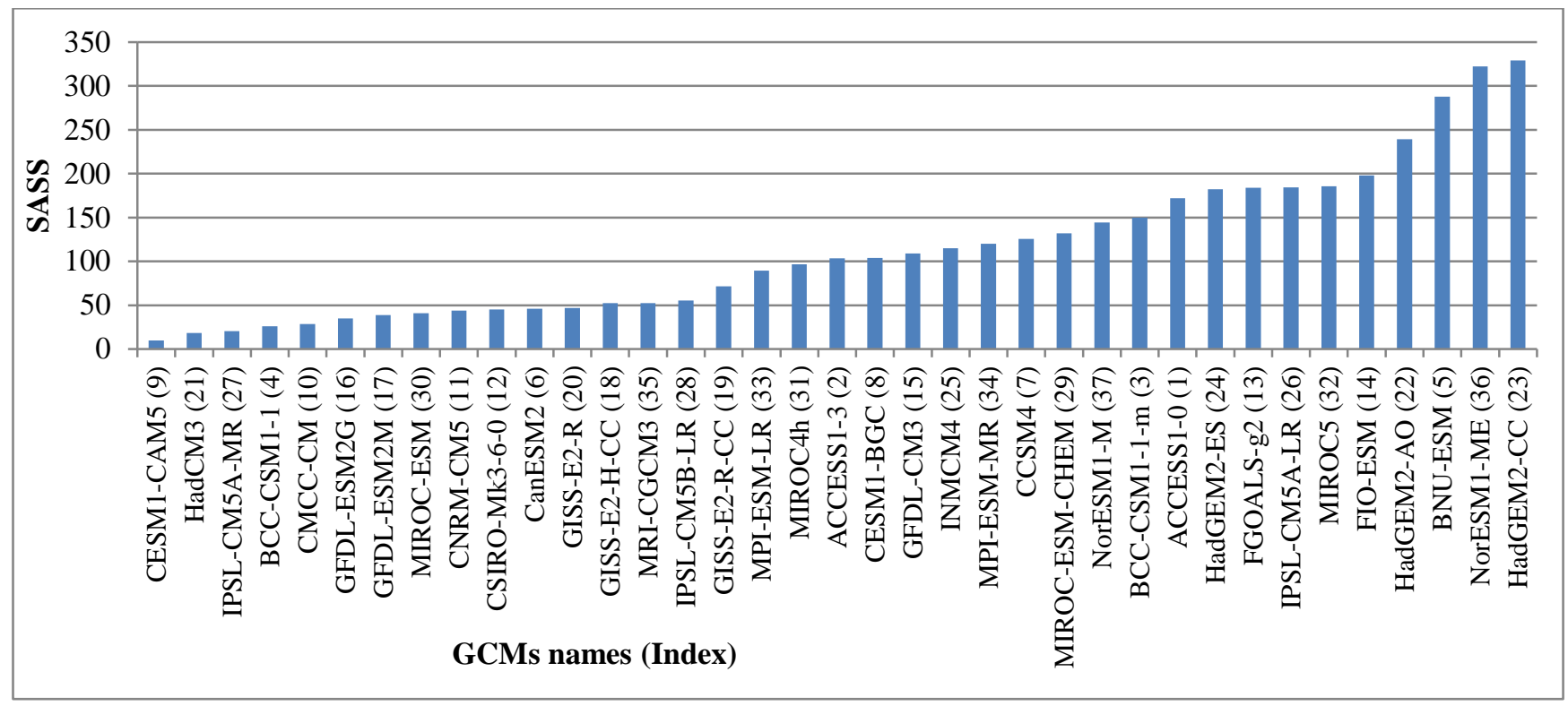

Fig. 4. Spatially average skill score (SASS) for various CMIP5 GCMs

\subsection{Trend Detection}

A comparison is made among annual and seasonal (SWM, NEM, PM and WS) precipitation time series for observed and downscaled data. The comparison is in terms of: (1) spatial trends of precipitation time series over the Ganga Basin which lies in the Indian administrative boundary; (2) temporal trends of precipitation time series in terms of $\mathrm{Z}_{\mathrm{MK}}$ and $\beta$; and (3)

15 scenario-wise comparison of trends in observed and downscaled precipitation time series for all AR5 (RCP2.6, RCP4.5, RCP6.0 and RCP8.5) emission scenarios of IPCC.

Plots indicating the spatial variation of $\mathrm{Z}_{\mathrm{MK}}$ and $\beta$ for annual and seasonal precipitation are presented in Fig 5 and 6 respectively. The color scale used (as shown in legends of these figures) indicates the significance of trends at certain significance levels, for example $\left|\mathrm{Z}_{\mathrm{MK}}\right|>1.645,1.960$ and 2.576 indicated significance of trends at $10 \%$, 5\% and $1 \%$ 
Hydrol. Earth Syst. Sci. Discuss., https://doi.org/10.5194/hess-2017-388

Manuscript under review for journal Hydrol. Earth Syst. Sci.

Discussion started: 17 July 2017

(c) Author(s) 2017. CC BY 4.0 License.

significance levels respectively. The plots provide a spatio-temporal comparison among observed and downscaled precipitation for all considered AR5 scenarios.

\subsubsection{Detection of trend in precipitation: Annual and Southwest monsoon season}

It can be observed that the $\mathrm{Z}_{\mathrm{MK}}$ and $\beta$ computed for gridded-observed-precipitation series is showing highly non-uniform

5 spatial variation over the study area for annual as well as seasonal time series. A comparable spatial trend can be seen between annual and SWM seasonal observed precipitation as the clusters of significant rising trends can be observed in the portion of study area adjacent to Himalayas as well as downstream side of River Ganga (eastern portion of study area) whereas significant falling trends are observed in the central portion of study area. Insignificant trends in observed precipitation can be seen in remaining part of study area.

10 As per $\mathrm{Z}_{\mathrm{MK}}$ (Fig. 5), for all AR5 future scenarios the precipitation time series is showing a dominant rising trend in annual and SWM season near Himalayas. For lower emission scenario (RCP2.6), insignificant trend is observed in most part of study area. As per $\beta$ (Fig. 6), the magnitudes of slopes for downscaled precipitation are smaller $(0<\beta<1.645)$ for lower emission scenarios (RCP2.6) throughout the basin. The area classified under higher magnitudes of slopes $(\beta>1.960)$ increases as we observe it from lower emission scenarios to higher emission scenarios.

\section{4.2.2 Detection of trend in precipitation: North-East monsoon season (Post-monsoon)}

In case of observed precipitation for NEM season (Fig. 5), a mixture of significant negative and insignificant trends are detected in upper and middle reaches of River Ganga respectively, with insignificant trends being spatially pre-dominant throughout the study area.. Similar pattern can be seen in $\beta$ (Fig. 6) for observed precipitation, with $\beta$ being negative ($1.645<\beta<0)$ in upper and middle reaches, and $\beta$ being positive $(0<\beta<1.645)$ in lower reaches of Ganga basin.

20 For downscaled precipitation, area under significant positive trends $\left(\mathrm{Z}_{\mathrm{MK}}\right)$ has a greater spatial coverage for all emission scenarios. The trend remains significant in western region for all emission scenarios except RCP 4.5. As per $\beta$ (Fig. 6), the downscaled precipitation has a mild positive slope $(0<\beta<1.645)$ which is spatially dominant throughout the study area for all the AR5 emission scenarios.

\subsubsection{Detection of trend in precipitation: Pre-monsoon season and winter season}

25 A spatially dominant insignificant trend can be observed all over the study area for observed as well as all RCPs. Small clusters of significant positive trend can be seen at the downstream side of Ganga (eastern portion of Ganga basin) for observed, RCP 2.6 and RCP 8.5 precipitation data, 
Hydrol. Earth Syst. Sci. Discuss., https://doi.org/10.5194/hess-2017-388

Manuscript under review for journal Hydrol. Earth Syst. Sci.

Discussion started: 17 July 2017

(c) Author(s) 2017. CC BY 4.0 License.

(c) (i)

\section{Hydrology and Earth System Sciences \\ Discussions}

$\mathbf{Z}_{\mathbf{M K}}$

Obs.
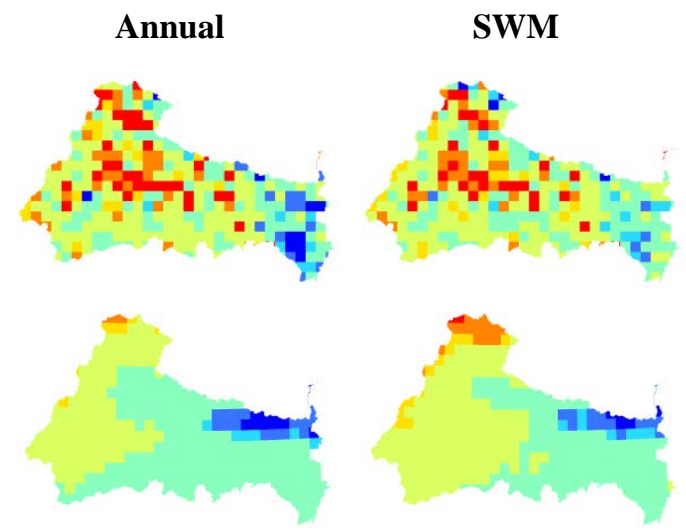

RCP2.6

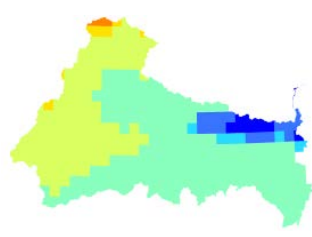

RCP4.5
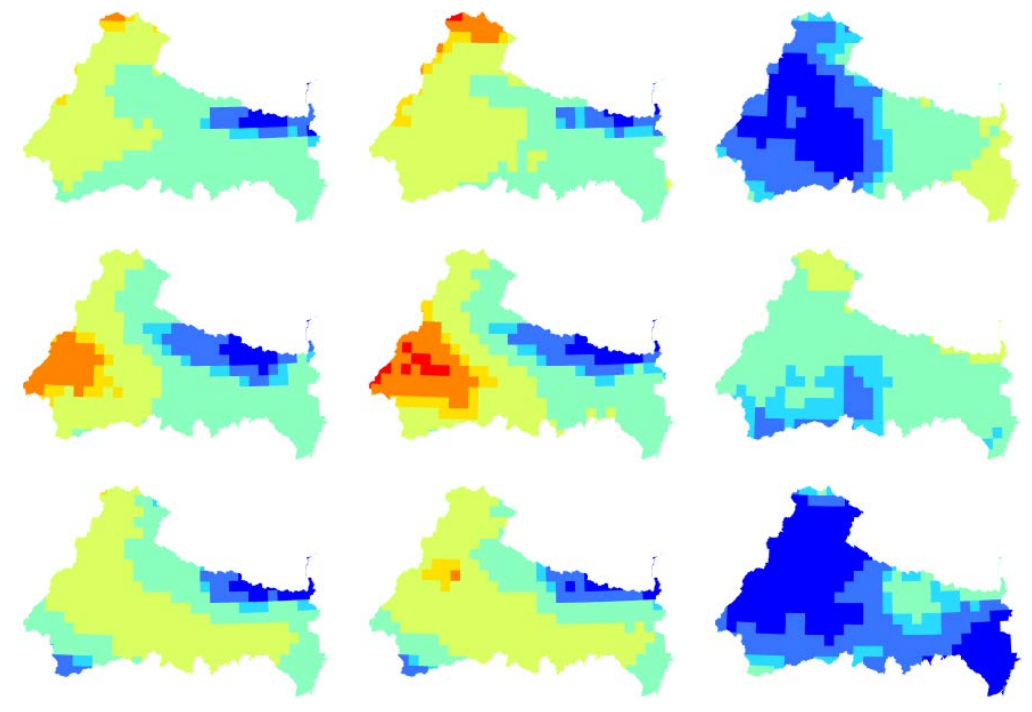

RCP8.5

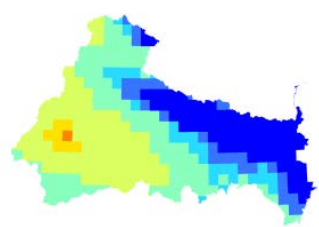

\section{Legend}

Mann Kendall statistic

Thiel Sen's slope
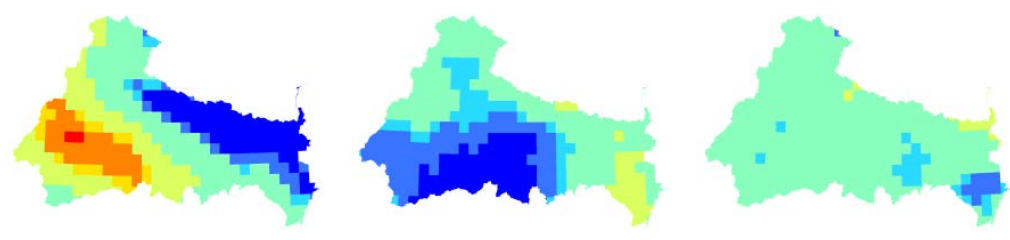

-2.576 and below

$-2.575--1.960$

$-1.959--1.645$

$-1.644-0.000$
WS
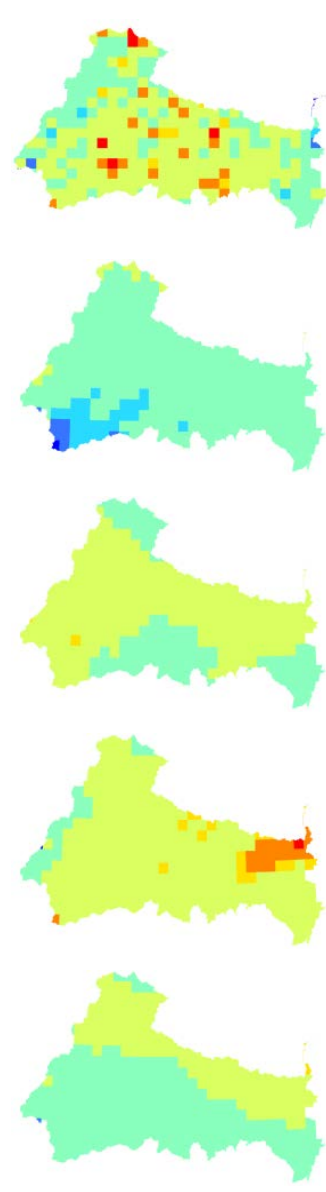

$0.001-1.645$

- $1.646-1.960$

$1.961-2.576$

2.577 and above

Figure 5: Spatio-temporal variation of Mann Kendall statistic $\left(Z_{\mathrm{MK}}\right)$ for annual and seasonal amounts of precipitation (observed and downscaled) over Ganga Basin in Indian administrative boundary 
Hydrol. Earth Syst. Sci. Discuss., https://doi.org/10.5194/hess-2017-388

Manuscript under review for journal Hydrol. Earth Syst. Sci.

Discussion started: 17 July 2017

(c) Author(s) 2017. CC BY 4.0 License.

(c) (i)

\section{Hydrology and Earth System Sciences \\ Discussions

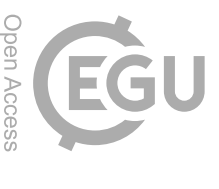

$\beta$ Annual SWM

NEM

PM

WS

Obs.
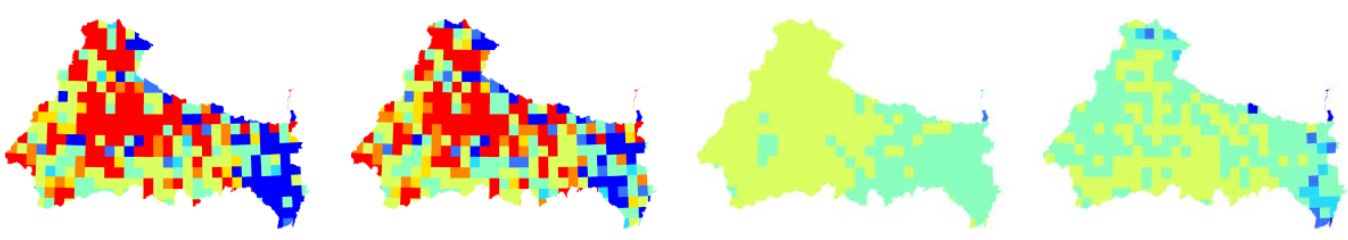

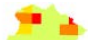

RCP2.6
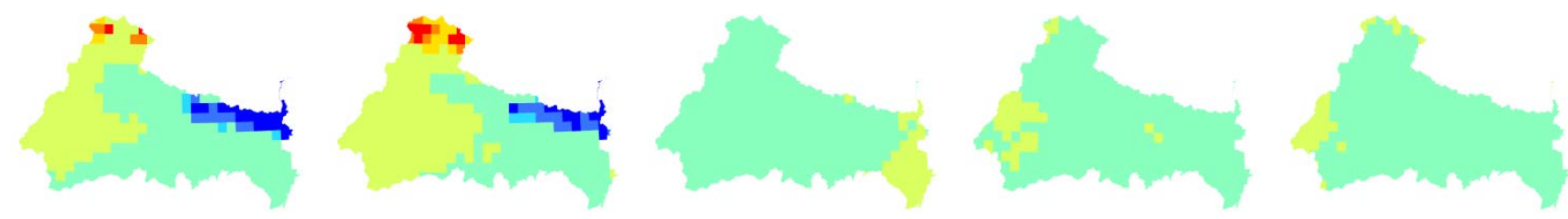

RCP4.5
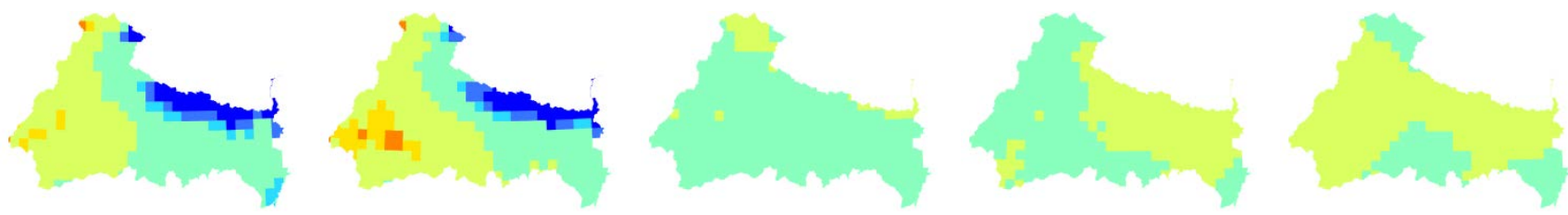

RCP6.0
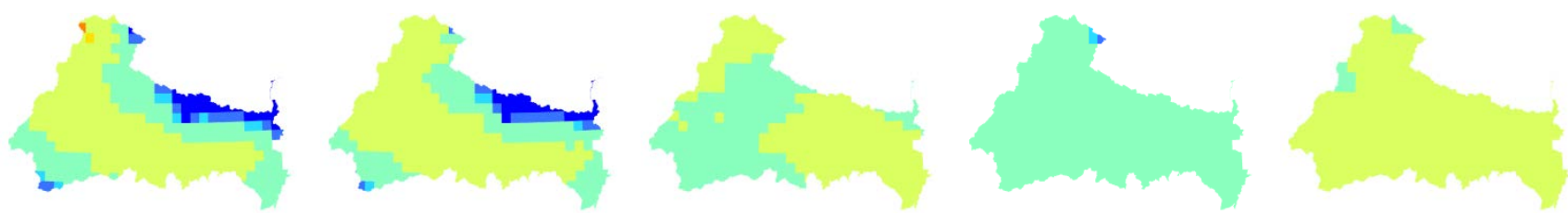

RCP8.5
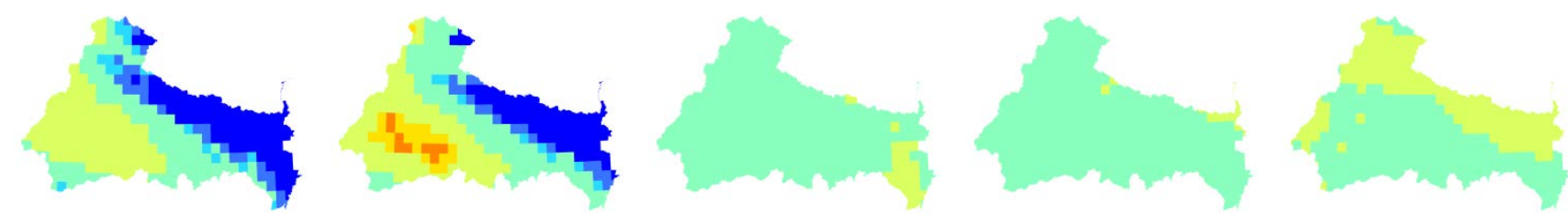

\section{Legend}

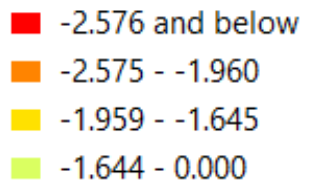

$0.001-1.645$

Mann Kendall statistic

Thiel Sen's slope

$-1.644-0.000$

ㅁ $1.646-1.960$

- $1.961-2.576$

2.577 and above

Figure 6: Spatio-temporal variation of Thiel Sen's slope ( $\beta$ ) for annual and seasonal amounts of precipitation (observed and downscaled) over Ganga Basin in Indian administrative boundary 
Hydrol. Earth Syst. Sci. Discuss., https://doi.org/10.5194/hess-2017-388

Manuscript under review for journal Hydrol. Earth Syst. Sci.

Discussion started: 17 July 2017

(c) Author(s) 2017. CC BY 4.0 License.

(c) (i)
Hydrology and

Earth System

Sciences

Discussions

\section{Conclusion}

In this paper a comprehensive methodology for comparison of precipitation trends among observed and all future emission scenarios is presented. Ranking of GCMs proved to be necessary to avoid the variability in ensemble of GCMs for a particular study area. USA-NCAR's GCM (CESM1-CAM5) proved to be the best performing GCM for precipitation over

5 Ganga basin. Plots are prepared to show the spatial distribution and comparison of trends based on Mann-Kendall's statistic and Thiel-Sen's slope. In case of observed precipitation, the spatial variation of trends is found to be highly non-uniform as compared to downscaled precipitation. The spatio-temporal-scenariowise comparison is performed for annual and seasonal precipitation showed that the precipitation amounts for annual and south-west monsoon seasonal time scales are going to increase significantly in the north eastern side of study area for all future emission scenarios but subsequently decrease

10 significantly in the western side. The spatial coverage for significant positive trends in precipitation is also increasing with higher emission scenarios. For post-monsoon season (NEM), the western side of study area is showing a significant increasing trend and rest of the area is showing insignificant trends for precipitation. In case of pre-monsoon and winter season, downscaled future precipitation is showing an insignificant trend in major portion of study area. As this study gives an inter-scenario comparison of projected precipitation in $21^{\text {st }}$ century, therefore, this study could be very useful for the

15 future planning and development of water resources in agriculturally dominated areas of Ganga basin.

\section{Abbreviations}

AR5: Assessment Report 5

$\beta$ : Thiel-Sen's slope estimate

BCSD: Bias-correction and spatial disaggregation

20 CMIP5: Coupled Model Intercomparison Project phase 5

IPCC: Intergovernmental Panel on Climate Change

Pobs: Observed Precipitation Series

RCP: Representative Concentration Pathways

WCRP: World Climate Research Program

$25 \mathrm{Z}_{\mathrm{MK}}$ : Mann-Kendall's test statistic

\section{Acknowledgements}

The authors acknowledge the World Climate Research Programme's Working Group on Coupled Modelling, which is responsible for CMIP, and we thank the climate modeling groups for producing and making available their model output. For CMIP the U.S. Department of Energy's Program for Climate Model Diagnosis and Intercomparison provides 
Hydrol. Earth Syst. Sci. Discuss., https://doi.org/10.5194/hess-2017-388

Manuscript under review for journal Hydrol. Earth Syst. Sci.

Discussion started: 17 July 2017

(c) Author(s) 2017. CC BY 4.0 License.

coordinating support and led development of software infrastructure in partnership with the Global Organization for Earth System Science Portals.

\section{References}

Adam, J. C. and Lettenmaier, D. P.: Adjustment of global gridded precipitation for systematic bias, J. Geophys. Res., 108, 15 14, doi:10.1029/2002JD002499, 2013.

Adamowski, K. and Bougadis, J.: Detection of trends in annual extreme rainfall, Hydrol. Process., 17, 3547-3560, doi:10.1002/hyp.1353, 2003.

Anandhi, A. and Nanjundiah, R., S.: Performance evaluation of AR4 Climate Models in simulating daily precipitation over the Indian region using skill scores, Theor. Appl. Climatol., 119, 551-566, doi:10.1007/s00704-013-1043-5, 2015.

10 Arora, H., Ojha, C.S.P., and Kashyap, D.: Effect of Spatial Extent of Atmospheric Variables on Development of Statistical Downscaling Model for Monthly Precipitation in Yamuna-Hindon Interbasin, India, J. Hydrol. Eng., 21(9), 05016019-1-17, doi: 10.1061/(ASCE)HE.1943-5584.0001400, 2016.

Basistha, A., Arya, D. S., and Goel, N. K.: Analysis of historical changes in rainfall in the Indian Himalayas, Int. J. Climatol., 29, 555-572, doi:10.1002/joc.1706 , 2009.

15 Barua, S., Muttil, N., Ng, A. W. M., and Perera, B. J. C.: Rainfall trend and its implications for water resource management within the Yarra River catchment, Australia, Hydrol. Process., 27, 1727-1738, doi: 10.1002/hyp.9311, 2013.

Beecham, S. and Chowdhury, R. K.: Temporal characteristics and variability of point rainfall: a statistical and wavelet analysis, Int. J. Climatol., 30, 458-470, doi:10.1002/joc.1901, 2010.

Caloiero, T., Coscarelli, R., Ferrari, E., and Mancinia, M.: Trend detection of annual and seasonal rainfall in Calabria

20 (Southern Italy), Int. J. Climatol., 31, 44-56, doi:10.1002/joc.2055, 2011.

Duhan, D. and Pandey, A.: Statistical analysis of long term spatial and temporal trends of precipitation during 1901-2002 at Madhya Pradesh, India, Atmospheric Research, 122, 136-149, doi:10.1016/j.atmosres.2012.10.010, 2013.

Fu, G., Liu, Z., Charles, S. P., Xu, Z., and Yao, Z.: A score-based method for assessing the performance of GCMs: A case study of southeastern Australia, J. Geophys. Res. Atmos., 118, 4154-4167, doi:10.1002/jgrd.50269, 2013.

25 Gallego, M. C., Trigo, R. M., Vaquero, J. M., Brunet, M., García, J. A., Sigró, J., and Valente, M. A.: Trends in frequency indices of daily precipitation over the Iberian Peninsula during the last century, J. Geophys. Res., 116, D02109, doi:10.1029/2010JD014255, 2011.

Mujumdar, P. P. and Ghosh, S.: Modeling GCM and scenario uncertainty using a possibilistic approach: Application to the Mahanadi River, India, Water Resour. Res., 44(6), W06407, doi:10.1029/2007WR006137, 2008.

30 Grotch, S. L. and MacCracken, M. C.: The Use of General Circulation Models to Predict Regional Climatic Change, J. Clim., 4, 286-303, doi:10.1175/1520-0442(1991)004<0286:TUOGCM>2.0.CO;2, 1991. 
Hydrol. Earth Syst. Sci. Discuss., https://doi.org/10.5194/hess-2017-388

Manuscript under review for journal Hydrol. Earth Syst. Sci.

Discussion started: 17 July 2017

(c) Author(s) 2017. CC BY 4.0 License.
Hydrology and

Earth System

Sciences

Discussions

Guhathakurta, P. and Rajeevan, M.: Trends in the rainfall pattern over India, Int. J. Climatol., 28, 1453-1469, doi:10.1002/joc.1640, 2008.

Guhathakurta, P., Shreejith, O. P., and Menon, P. A.: Impact of climate change on extreme rainfall events and flood risk in India, J. Earth Syst. Sci., 120(3), 359-373, doi:10.1007/s12040-011-0082-5, 2011.

5 Helsel, D.R.: Advantages of nonparametric procedures for analysis of water quality data, Hydrolog. Sci. J., 32, 179-190, doi:10.1080/02626668709491176, 1987.

Hirsch, R. M., Slack, J. R., and Smith, R. A.: Techniques of Trend Analysis for Monthly Water Quality Data, Water Resour. Res., 18(1), 107-121, doi:10.1029/WR018i001p00107, 1982.

IPCC: Climate Change 2007 - The Physical Science Basis, Contribution of Working Group I to the Fourth Assessment

10 Report of the Intergovernmental Panel on Climate Change (IPCC). Solomon, S., Qin, D., Manning, M., Marquis, M., Averyt, K., Tignor, M. M. B., Miller, HLR Jr., Chen, Z. Cambridge Univ. Press, Cambridge, UK, 2007.

IPCC: Climate Change 2013 - The Physical Science Basis, Contribution of Working Group I to the Fifth Assessment Report of the Intergovernmental Panel on Climate Change (IPCC). Stocker, T. F., Qin, D., Plattner, G-K, Tignor M. M. B., Allen, S. K., Boschung, J., Nauels, A., Xia, Y., Bex, V., Midgley, P. M. Cambridge Univ. Press, Cambridge, UK, 2013.

15 Jain, S.K. and Kumar, V.: Trend analysis of rainfall and temperature data for India, Curr. Sci. India, 102(1), 37-49, 2012.

Kendall, M. G.: Rank Correlation Methods, Charles Griffin, London, 1975.

Kothyari, U. C., Singh, V. P., and Aravamuthan, V.: An Investigation of Changes in Rainfall and Temperature Regimes of the Ganga Basin in India, Water Resour. Manag., 11, 17-34, doi:10.1023/A:1017936123283, 1997.

Kumar, R., Stephens, M., and Weir, T.: Rainfall trends in Fiji, Int. J. Climatol., 34(5), 1501-1510, doi:10.1002/joc.3779, 202013.

Lettenmaier, D. P., Wood, E. F., and Wallis, J. R.: Hydro-climatological trend in the continental United States 1948-88, J. Climate, 7(4), 586-607, doi:10.1175/1520-0442(1994)007<0586:HCTITC>2.0.CO;2, 1994.

Mann, H. B.: Non-parametric tests against trend, Econometrica, 13, 245-259, 1945.

Maurer, E. P., Brekke, L., Pruitt, T., and Duffy, P. B.: Fine-resolution climate projections enhance regional climate change

25 impact studies, Eos Trans. AGU, 88(47), 504, doi:10.1029/2007EO470006, 2007.

Maurer, E.P., Adam, J.C., and Wood, A.W.: Climate Model based consensus on the hydrologic impacts of climate change to the Rio Lempa basin of Central America, Hydrol. Earth Sys. Sc., 13, 183-194, doi:10.5194/hess-13-183-2009, 2009.

Meehl, G. A., Covey, C., Delworth, T., Latif, M., McAvaney, B., Mitchell, J. F. B., Stouffer, R. J., and Taylor, K. E.: The WCRP CMIP3 multi-model dataset: A new era in climate change research, B. Amer. Meteorol. Soc., 88, 1383-1394, 30 doi:10.1175/BAMS-88-9-1383, 2007.

Ojha, R., Kumar, D.N., Sharma, A., and Mehrotra, R.: Assessing GCM convergence for the Indian region using the variable convergence score, J. Hydrol. Eng., 19(6), 1237-1246, doi: 10. 1061/(ASCE) HE.1943-5584.0000888, 2014. 
Hydrol. Earth Syst. Sci. Discuss., https://doi.org/10.5194/hess-2017-388

Manuscript under review for journal Hydrol. Earth Syst. Sci.

Discussion started: 17 July 2017

(C) Author(s) 2017. CC BY 4.0 License.

(c) (i)
Hydrology and

Earth System

Sciences

Discussions

Perkins, S.E., Pitman, A.J., Holbrook, N.J., and McAveney, J.: Evaluation of the AR4 climate models' simulated daily maximum temperature, minimum temperature and precipitation over Australia using probability density functions, J. Climate, 20, 4356-4376, doi:10.1175/JCLI4253.1, 2007.

Partal, T. and Kahya, E.: Trend analysis in Turkish precipitation data, Hydrol. Process., 20(9), 2011-2026, 5 doi:10.1002/hyp.5993, 2006.

Peel, M. C., Finlayson, B. L., and McMahon, T. A.: Updated world map of the Koppen-Geiger climate classification, Hydrol. Earth Syst. Sci., 11, 1633-1644, doi:10.5194/hess-11-1633-2007, 2007.

Raju, K. S. and Nagesh Kumar, D.: Ranking of CMIP5-based global climate models for India using compromise programming, Theor. Appl. Climatol., 128 (3-4), 563-574, doi:10.1007/s00704-015-1721-6, 2017.

10 Sen, P.K.: Estimates of the regression coefficient based on Kendall's tau. J. Am. Stat. Assoc. 63, 1379-1389, 1968.

Taylor, K.E., Stouffer, R.J., and Meehl, G.A.: An Overview of CMIP5 and the Experiment Design, Bull. Amer. Meteor. Soc., 93(4), 485-498, doi:10.1175/BAMS-D-11-00094.1, 2012.

Theil, H.: A rank-invariant method of linear and polynomial regression analysis: 1, Proc. K. Ned. Akad. Wet., 53, 386-392, 1950a.

15 Theil, H.: A rank-invariant method of linear and polynomial regression analysis: 2, Proc. K. Ned. Akad. Wet., 53, 521-525, 1950b.

Theil, H.: A rank-invariant method of linear and polynomial regression analysis: 3, Proc. K. Ned. Akad. Wet., 53, 13971412, 1950c.

Vuuren, D. P. v., Edmonds, J., Kainuma, M., Riahi, K., Thomson, A., Hibbard, K., Hurtt, G. C., Kram, T., Krey, V.,

20 Lamarque, J-F, Masui, T., Meinshausen, M., Nakicenovic, N., Smith, S. J., Rose, S. K.: The representative concentration pathways: an overview, Climatic Change, 109, 5-31, doi:10.1007/s10584-011-0148-z, 2011.

Wood, A. W., Leung, L. 5 R., Sridhar, V., and Lettenmaier, D. P.: Hydrologic implications of dynamical and statistical approaches to downscaling climate model outputs, Climatic Change, 62(1-3), 189-216, doi:10.1023/B:CLIM.0000013685.99609.9e, 2004. 